\title{
African Studies Keyword: Oil
}

\author{
John R. Heilbrunn (1)
}

\begin{abstract}
Oil is a metonym for terms in books and articles in diverse disciplines in African studies. Some portray oil as a causal agent that thrusts formerly low-income countries into the highly competitive neoliberal global economy. Others present it according to the oil curse/blessing binary. As a curse, petroleum causes dysfunctional and costly behavior. But increased revenues from oil just as certainly result in concrete improvements demonstrating a resource blessing. Heilbrunn uses case materials to explore environmental degradation, oil theft, community-company relations, postconflict reconstruction, local content in contracts, and corruption. These key concepts form a basis for the keyword/concept essay on oil in Africa.
\end{abstract}

Résumé: Le pétrole est un terme métonymique dans les livres et articles de diverses disciplines des études africaines. Certains dépeignent le pétrole comme un agent causal qui propulse des pays autrefois à faible revenu dans l'économie mondiale néolibérale hautement compétitive. D’autres le présentent selon le binaire malédiction/bénédiction du pétrole. En tant que malédiction, le pétrole entraîne des comportements dysfonctionnels et coûteux. Mais l'augmentation des revenus du pétrole entraîne tout aussi certainement des améliorations concrètes, ce qui démontre que les ressources sont une bénédiction. Heilbrunn utilise des cas concrets pour explorer la dégradation de l'environnement, le vol de pétrole, les relations entre les communautés et les entreprises, la reconstruction post-conflit, le contenu local des contrats et

African Studies Review, Volume 64, Number 2 (June 2021), pp. 458-483

John R. Heilbrunn, PhD, is Associate Professor Emeritus at the Colorado School of Mines. He is also a research fellow (Chercheur associé) at Les Afriques dans le Monde (LAM), a research unit of SciencesPo-Bordeaux. Heilbrunn taught at Mines for 20 years where he specialized in the political economy of development in Africa, natural resource management, public sector reform, and governance and anticorruption. He is the author of numerous articles and Oil, Development, and Democracy in Africa (Cambridge 2014). Heilbrunn is currently preparing a manuscript on commodity cartels in developing countries.

(C) The Author(s), 2021. Published by Cambridge University Press on behalf of the African Studies Association. This is an Open Access article, distributed under the terms of the Creative Commons Attribution licence (http:/ / creativecommons.org/ licenses/by/4.0/), which permits unrestricted re-use, distribution, and reproduction in any medium, provided the original work is properly cited.

doi: $10.1017 /$ asr.2021.30 
la corruption. Ces concepts clés constituent la base du mot clé/ concept sur cet essai sur le pétrole en Afrique.

Resumo: O petróleo é uma palavra metonímica usada recorrentemente em livros e artigos de diversas disciplinas dos Estudos Africanos. Há autores que apresentam o petróleo como um agente causal que lança países outrora de baixo rendimento para o centro da economia mundial neoliberal e altamente competitiva. Outros autores apresentam-no à luz do binómio bênção/maldição. Enquanto maldição, o petróleo dá origem a comportamentos disfuncionais e dispendiosos. Mas o aumento dos rendimentos derivados do petróleo resulta também, inevitavelmente, em melhorias concretas, demonstrado tratar-se de um recurso abençoado. Heilbrunn utiliza dados de estudos de caso para analisar a degradação ambiental, o roubo de petróleo, as relações entre as comunidades e as empresas petrolíferas, a reconstrução do pósguerra, os conteúdos locais dos contratos e a corrupção. Estes conceitos-chave constituem uma base de partida para este ensaio sobre palavras-chave e conceitos relacionados com o petróleo em África.

Keywords: Oil; petroleum; hydrocarbons

(Received 3 March 2020 - Revised 17 February 2021 - Accepted 19 February 2021)

\section{Introduction}

In Africa, as elsewhere in the world, the discovery of subterranean pools of hydrocarbons for which extraction is commercially viable is transformative. ${ }^{1}$ Earnings from oil production finance social sector spending (education, health, and employment-generating investments) and essential services and related businesses. Simply put, oil is wealth. However, any discussion of oil calls for a nuanced approach. Following the discovery, the oil industry attracts all kinds of actors including international companies, local entrepreneurs, opportunistic authorities, honest politicians, and, sadly, unscrupulous individuals.

Oil, a powerful African studies keyword, is no less a metonym for a cluster of terms in the African studies literature. It is a word of diverse meanings that sparks polemical writings. Some use petroleum as a causal agent that thrusts formerly low-income countries into the highly competitive neoliberal world economy. Another influential usage is the oil curse/blessing binary. This debate is a powerful polemic that has shaped many discussions and analyses. Viewed as a curse, petroleum causes dysfunctional behavior and real problems. However, increased revenues just as certainly result in concrete improvements. How one balances the ledger determines where one lands in the curse/blessing debate. Indeed, these debates, among others, highlight how different usages of the term characterize an industry that is increasingly omnipresent on the continent. 
In 2020, approximately thirty African countries were exporting hydrocarbons. Here I focus on four producers and exporters-Angola, Chad, Equatorial Guinea, and Nigeria-and examine the different oil terminologies present in diverse disciplinary and interdisciplinary studies, particularly interpretive political science, macroeconomics, anthropology, and sociology. My goal is to animate a conversation about how various disciplines discuss specific terms and concepts related to petroleum production in Africa. Because so many scholars debate the variable impact of hydrocarbons, much of the writing is in disciplinary silos. Some scholars appear unaware of contributions from other fields; they use terms and concepts that reflect their own disciplinary epistemologies and fail to connect to other fields. Research on petroleum requires interdisciplinarity.

Hence, I assemble the oil keyword as a composite from six subordinate terms or concepts which are presented in six sections. After a brief introduction to the four country case studies, I discuss the concept of resource revenue management. I note how corporate and political actors negotiate contracts that include local content requirements (LCRs); oil companies agree to invest in infrastructure, social sector expenditures, and training (Ovadia 2014; Ovadia 2016b; Hilson \& Ovadia 2020). Fiscal regimes, a technical term from the economic development literature, denotes the contractual arrangements that structure the petroleum sector. I then consider "oil" as a metaphor for energy, energy justice, modernity, and neoliberalism. These terms inform diverse studies of oil exporting countries. The third discussion analyzes the resource curse/blessing dichotomy debated in the political science/political economy literature. Whereas the oil curse thesis presents oil as a cause of lower rates of economic growth, dictatorship, gender inequalities, violent war, and environmental destruction, the blessing thesis sees oil as wealth that can be used to improve public services, promote gender equality, contribute to political efficacy, and embed democratic practices. The next section analyzes how oil production has caused shocking environmental destruction. Companies, often negligently, fail to maintain security or the integrity of the oil pipelines, leading to spills that deepen poverty, unemployment, and injustice in oil producing regions. I then turn to oil as community, and in particular how people respond to the displacements wrought by oil production. Members of local communities compose an oil complex of actors that interact in the value chain. In the final section, I turn to corruption. Although corruption is evident in the theft of billions of dollars by dishonest officials and their collusive partners in oil companies, its occurrence is most evident in countries where agencies of control were nonexistent when hydrocarbon production began.

Map 1 displays the extraordinary wealth found on the African continent. Although it does show the hydrocarbons in the four countries discussed in this essay, it neglects the hydrocarbons in Ghana, South Africa, and Uganda and natural gas in Tanzania and Mozambique. This omission is unfortunate, because the discoveries in East Africa promise an exponential increase in the wealth of those countries. 


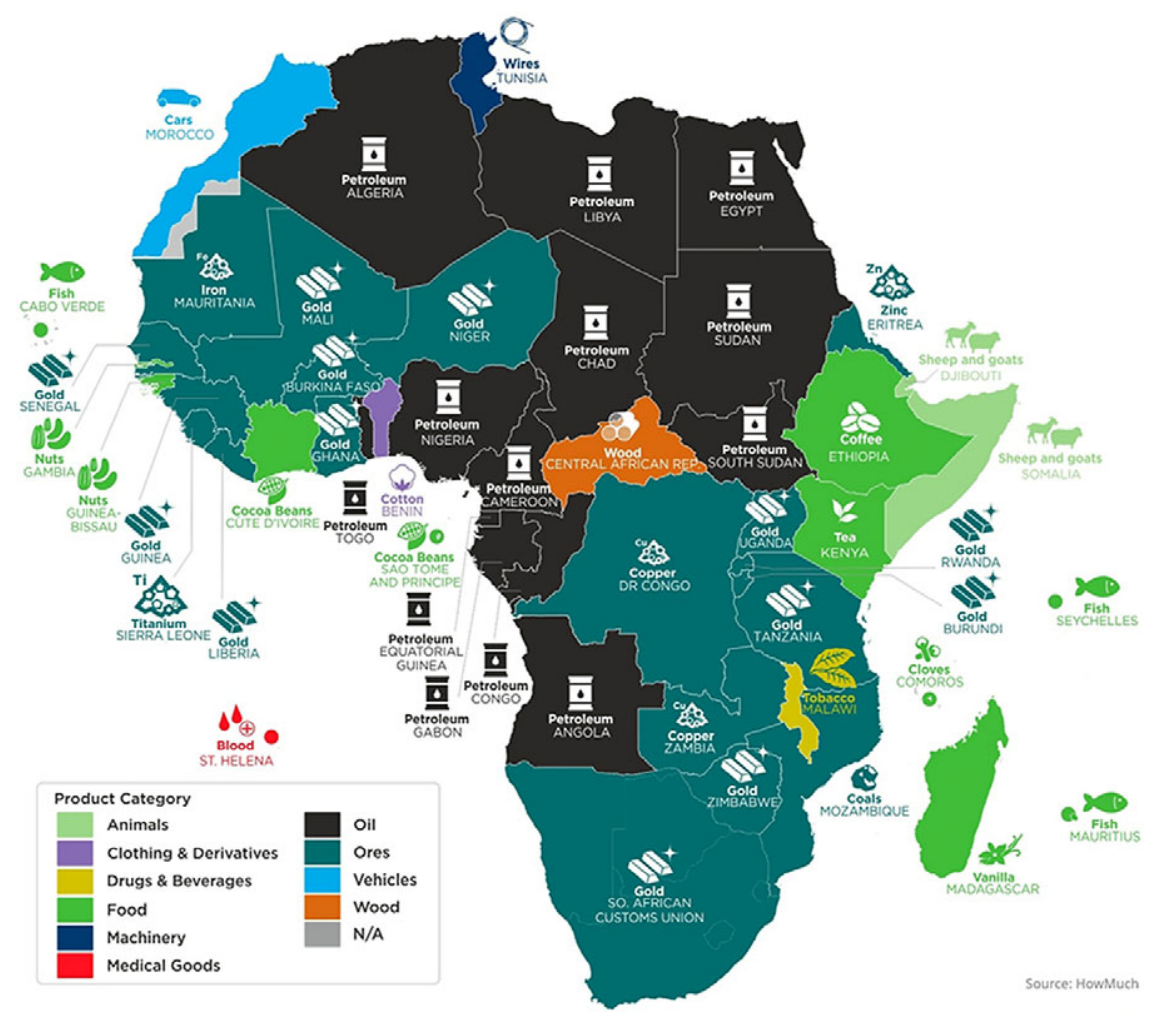

Map 1. Source: http://visualcapitalist.com, accessed February 4, 2021.

\section{Oil Producers: Nigeria, Angola, Chad, and Equatorial Guinea}

Nigeria, Angola, Chad, and Equatorial Guinea illustrate the impact of oil on African societies. When agencies of control do not exist, opportunities for corruption abound. However, it is likely that as oil exporting countries receive more wealth, the revenues enable state construction that includes more agencies of horizontal accountability. After agencies of horizontal accountability are established, policymakers are incentivized to use the revenues efficiently. In effect, oversight of the oil production value chain (exploration, extraction, depositing royalties, taxes, and fees in government accounts, refining, and marketing) earns more revenues for the exporting country. Movement along the oil value chain begins with exploration and progresses quickly to extraction and the depositing of bonuses, royalties, taxes, and fees. It is neither linear nor without mishap and resistance from officials.

As a chemical, oil's comparative quality kindles different companies' enthusiasm to invest in a country, thereby enhancing its relative international 
importance. Quality varies according to a crude oil's density, sulfur content, and pour point (Smil 2003:15). Petroleum's density is either light or heavy, as measured in degrees of American Petroleum Institute (API) gravity. A heavier oil costs more to extract. Crude oil with a low hydrogen sulfide content is called sweet, and it is cheaper to refine. Once reserves have been located in subterranean reservoirs, the oil's API gravity and composition must be determined. Profits are a function of the cost of extraction and refining. It is the oil's quality that attracts companies, according to the market value of the crude they hope to extract. The market value of a sweet light crude is higher than that of a heavy sour oil.

Governments of oil exporting countries that depend on revenues for fiscal expenditures are vulnerable to price volatility and exogenous shocks. In periods of prices downturns and exogenous shocks, countries with highquality oil continue production, but in those countries with heavy, sour crude, production slows. In early 2020, the global pandemic, an exogenous shock, seriously reduced the demand for oil, and petroleum companies cut production. Fiscal revenues crashed as the value of a barrel of oil dropped so low that some African governments needed to borrow money to pay basic public sector services. How the price crash, diminished revenues, and funding cuts disrupted each oil exporting country's public sector services is an unfolding story. Disruptions have compelled policymakers to re-evaluate their countries' dependence on resource revenues.

Petroleum production has increased dramatically since the 1957 discoveries in colonial Nigeria and Gabon. By 2020, almost thirty African countries were exporting oil. Petroleum represents a crucial source of revenues for all of these countries. Although hydrocarbon production contributes to an increase in gross domestic product, negative impacts include the "Dutch disease," wherein factors of production move to the booming natural resource sector, leaving the economy vulnerable to price downturns (Corden \& Neary 1982). In each exporting country, the industry has contributed to the emergence of what Michael Watts (2015) and Jane Guyer (2015) respectively call an "oil complex" or "oil assemblage.” Organizations and actors emerge and cluster around the sector, seeking rents and wealth. Positive entrepreneurial behavior among local populations occurs alongside wretched venality and sometimes violent criminality.

Nigeria is sub-Saharan Africa's leading hydrocarbon producer. This extraordinarily dynamic country has a diversified economy that is the largest in Africa. Although Nigeria possesses 34 billion proven barrels of sweet, light crude, petroleum has had an uneven impact on the country's over 200 million inhabitants. The oil reserves are mostly in the Niger Delta, a coastal plain of approximately 70,000 square kilometers that hosts 30 million people (Watts 2004). In addition to crude oil, Nigeria has over 200 trillion cubic feet (TCF) of proven natural gas fields and a further 600 TCF in unproven fields. In short, Nigeria is a giant in all senses.

To manage its oil sector, Nigeria has a highly complex fiscal regime. The Nigerian National Petroleum Company receives a portion of the crude oil 
lifted by concessionaries. Companies make deposits into the unmonitored Domestic Crude Allocation accounts that are controlled by the NNPC (Sayne et al. 2015:16). Frequent corruption scandals have involved stunning sums of money (Gillies 2020). Indictments of dishonest Nigerian officials have resulted in few incarcerations and account for Transparency International's (TI) 2019 Corruption Perception Index ranking of Nigeria as 146 of 180 countries.

Angola is sub-Saharan Africa's second leading oil exporter. Oil production began in 1967; however, it has been declining substantially since 2019. Today, Angola possesses reserves of 9.5 billion barrels almost entirely in deepwater blocks located in the Lower Congo Basin (IMF 2018:6). Its population of 30 million inhabitants includes an emerging middle class. Before the global pandemic, Angola had one of the world's fastest growing economies. From 1979 until 2018, Jose Eduardo Dos Santos was General Secretary of the ruling Popular Movement for the Liberation of Angola (Movimento Popular de Libertação de Angola-MPLA) and president of Angola. Through management of the state-owned oil company, Sonangol, Dos Santos, his children, and associates in the army and MPLA amassed incredible fortunes (Soares De Oliveira 2007a).

After João Lourenço won the MPLA election in 2017, he became the General Secretary and president. Dos Santos moved to Barcelona to a life in exile. Even though he had left, legacies of poor governance were evident in his clan's grip on multiple productive sectors, often in collaboration with an oligarchy of military officers and regime cronies. Lourenço launched an anticorruption campaign in September 2018 and set about dismantling the Dos Santos clan networks. Exposés of the Dos Santos clan and their allegedly illgotten billions attest to the grip of corrupt individuals (Freedberg et al. 2020). Corruption is a serious issue in Angola. In 2019, TI ranked Angola 146 out of 180 countries.

Chad joined the African oil exporting community in 2001. From its reserves of 1.5 billion barrels of oil, Chad exports 130,000 barrels a day. Earnings from oil accounted for an increase in GDP from USD1.4 billion in 2000 to USD11.3 billion in 2019, with a concomitant increase in its per capita purchasing power parity (PPP) income from USD765 in 2000 to USD1,645 in 2019 (World Bank 2019). Meanwhile, primary school enrollment improved from 64 percent in 2000 to 88 percent in 2016 (World Bank 2019). Increases in income and school enrollment occurred in spite of the country's income inequality. Chad's fiscal regime includes concessions with cash-calls and equity participation (IMF 2019a:48). Unlike many African oil exporting countries, Chad is remarkable for its efforts at transparency and for the public availability of oil contracts (World Bank 2019:19). However, conflict, dictatorship, and venality have been common in Chad. Corruption is systemic, and this is reflected in the 2019 TI ranking of 162 out of 180 .

Equatorial Guinea is among the newer African oil producers. With a population of 1.355 million and an average annual GNI per capita of USD6,460 (World Bank 2019), oil looms large in the economy, accounting 
for nearly 90 percent of the country's exports. Despite the country's substantial petroleum wealth, common Equatoguineans have received few benefits from the millions gained from offshore oil production (Appel 2015). With the exception of its first election in 1968, which was democratic, brutally authoritarian regimes have ruled Equatorial Guinea. The country's first president, Francisco Macias Nguema, imposed a breathtakingly ruthless regime. His nephew, Teodoro Obiang Nguema Mbasogo, overthrew the government and ordered his uncle's execution in 1979. Obiang Nguema established a dynastic dictatorship in which he distributed the key offices of state to his clansmen, who have siphoned off the wealth earned from its offshore reserves. In short, the country is remarkable for relatively high economic growth rates, extreme income inequalities, corruption, and repression. Equatorial Guinea is among the world's most corrupt countries, such that in 2019 TI ranked it at 173 out of 180 .

\section{Resources \& Revenues}

Oil's vulnerability to exogenous shocks became starkly apparent in 2020, when the COVID-19 pandemic preceded a significant drop in prices. Oil companies began to sell down their assets, as the pandemic exposed the vulnerability of African states. Even before the pandemic, public officials had to negotiate contracts that included local content requirements. These provisions stipulate that international companies engage domestic firms and thereby keep a greater percentage of resource revenues in-country (Ovadia 2016a). Local content requirements are increasingly part of the fiscal regimes in African oil exporting countries. Although their impact on local communities should, normatively, be positive, compliance remains ambiguous.

Many countries, including Angola, Nigeria, and Ghana, require that contracts have local content policies to promote engagement with domestic companies (Ovadia 2016a:20-21; Ovadia 2016b; Hilson \& Ovadia 2020). Policymakers intend, thereby, to transform oil production and its impact on local communities. Angola and Nigeria had long ago inserted local content requirements into their contracts. Ghana, which became an oil exporting country after the Jubilee Field came into production in 2010, established the Enterprise Development Centre (EDC) to embed local content and build domestic capacity in oil and gas production (Ablo 2020:322).

Local content requirements demonstrate the importance of community voice in Africa's low- or low-middle-income oil exporting countries. People in communities know that their governments receive substantial sums of money from petroleum production and standardize "revenue collection, budget preparation, budget planning, expenditure execution, procurement, reporting and oversight" (Deléchat et al. 2015:5n7). These laws and rules compose the fiscal regime that set royalties, taxes, local content requirements, signature bonuses, and production sharing (Calder 2014). Responsibilities for the government include setting up accounts into which oil companies deposit payments, opening ministries to interact with investors, and establishing 
national oil companies to participate in production sharing and joint ventures.

Any fiscal regime is a product of negotiations between oil companies and national officials. In the late 1970s, Gobind Nankani (1979) drew attention to the asymmetries between highly trained oil executives who negotiated fiscal regimes and their far less-prepared African officials. Those disadvantages have ended. African states now employ local engineers and specialists trained at top European and North American universities. Many of these individuals began their careers with the supermajors-ExxonMobil, ChevronTexaco, Shell, BP, Total, or ConocoPhillips-and established domestic companies or worked for national oil companies such as Sonangol, the Nigerian National Petroleum Company, and the Ghanaian National Petroleum Company. They are every bit the equals of executives with the supermajors.

As an increasing number of African countries are now oil exporters, the effect of their adopting fiscal regimes is a process by which different countries construct new ministries, departments, and agencies to manage the industry. Of course, this process requires recruitment of competent personnel and enforcing fiscally responsible procedures. It seems probable that these new offices and employees may improve transparency in the petroleum sector and bring about greater accountability from public authorities.

\section{Oil as a metaphor}

Oil often functions as a metaphor for different policies and behaviors. For some, the substance signifies modernity, finance, geopolitics, or violence; it is the "ur-commodity, the mother of all commodities that enables all other commodities" (Appel, Mason, \& Watts 2015:10). Hydrocarbons are energy, whether to heat homes or to provide fuel for automobiles, trucks, aircrafts, and shipping. As energy, oil is part of a system wherein some people have access to its benefits while others do not. It is a measure of economic wellbeing. A recent concept has proposed that energy justice has eight elements, including availability, due process, good governance, sustainability, intergenerational equity, intragenerational equity, and responsibility (Sovacool \& Dworkin 2015:439). This normative theory "aims to provide all individuals, across all areas, with safe, affordable, and sustainable energy" (McCauley et al. 2013).

Petroleum production transfers to exporting countries the praxis of market capitalism (Schubert 2017:6). In Argentina, Elana Shever argues, oil is linked to neoliberalism, and its "profound state and economic restructuring" includes privatization of state companies, opening of markets to transnational corporations, and anti-labor policies (Shever 2012:11). Shever's triad recalls Michel Foucault's observation that neoliberalism shows "how the overall exercise of political power can be modeled on the principles of a market economy" (2004:131). It follows that oil production compels exporting countries to accept capitalist reasoning with its emphases on free 
markets, rational accounting, unorganized labor, and profits. Foucault notes that these practices can be "broken down, subdivided, and reduced, not according to the grain of individuals, but according to the grain of enterprises" (2004:241). It is the capitalist oil enterprises that determine policies and practices among national elites.

James Ferguson (2010) asserts that fiscally strapped African politicians had no choice but to accept neoliberal prescriptions that pushed them into the capitalist world economy. These prescriptions included privatization, fiscal management, and reforms derived from the Washington Consensus (Ferguson 2010; Williamson 1993; Harvey 2005; Watts 2018). For David Harvey, neoliberalism is "dispossession" and a process of taking money from the poor and transferring it to the wealthy (2005:159). Formerly impoverished oil-exporting countries were victims first of colonial rule, then of post-colonial dependency. Later, multilateral banks "crammed" neoliberal structural adjustment programs "down their throats" (Ferguson 2006:71). However, those who argue the neoliberal critique tend to portray African leaders and subjects in oil-exporting states as passive victims.

Neoliberalism is a term often used without definitional rigor beyond an unspecified conclusion that it refers to undesirable outcomes, including globalism, imperialism, privatization, and capitalism (Ferguson 2010:166). Rooted in this critique is a belief that oil production in Africa occurs in "our contemporary world of downsized states and unconstrained global corporations" (Ferguson 2005:378). The process of oil extraction in Africa contributes to the continent's continued "exclusion and marginalization" (Ferguson 2006:194). Neoliberal policies are "bad for the poor and working people" (Ferguson 2010:166). African leaders and their citizens are therefore victims of international organizations that "coerce" them to accept structural adjustment programs and "scientific capitalism" (Ferguson 2006:78).

Of course, even a cursory examination of the empirical record denies that if policymakers can just get it right (e.g. implement the reforms outlined in the Washington Consensus), then all good things will follow. Case after case suggests that this is not necessarily so. Indeed, Africa's extraordinary growth rates, especially in countries that resisted all the prescriptions embedded in structural adjustment programs, contradict the structural critiques of neoliberal theory. African oil exporting countries have emerged from extreme poverty according to their own fashion. Even as the impact of the global pandemic is slowing economic growth, African oil exporters continue to receive resource revenues. Their policymakers may very well use these revenues to finance new state organizations that promise more effective government.

\section{The Curse/Blessing Dichotomy}

Dichotomous reasoning has contributed to polemical studies that onesidedly fail to explain how petroleum influences African life. The "resource curse" theory for one is a deterministic perspective for which the scenario is 
simple: oil companies discover reserves, production begins, economic growth follows, exchange rate distortions consistent with the Dutch disease harm the economy, poverty increases, and political leaders impose authoritarian regimes (Auty 1994; Ross 2012). Jeffrey Sachs and Andrew Warner (1995) correlate abundant natural resources with an enormous number of variables to show "empirically" negative impacts. Terry Lynn Karl (1997) and Michael Ross (2001) developed resource (oil) curse arguments stating that in economies with abundant hydrocarbon resources, growth is elusive. For their acolytes, politicians consolidate corrupt dictatorships (Gillies 2020; Jensen \& Wantchekon 2004; Tsui 2011). Nicholas Shaxson (2007:7) asserts that it is not "oil companies but oil itself-the corrupting poisonous substance." Women and the poor often suffer disproportionately (Ross 2012). It is a dreadful picture.

However, overly deterministic arguments resting on saturated statistical models have obscured causal inference and raised doubts about the theory. Arguments for the resource curse were that political leaders of countries with abundant natural resources always adopt inefficient policies or impose autocracy. Skeptics questioned this dogma, asserting that natural resources were really a blessing. As Thad Dunning commented, "Resource rents can promote authoritarianism or democracy, but they do so by different mechanisms" (2008:4). Economists Michael Alexeev and Robert Conrad (2009) showed that oil production is actually a net benefit to low-income countries. Stephen Haber and Victor Menaldo (2011) argued that critical data suggest that petroleum enhances democracy. Kelsey O'Connor and associates (2018) used time series data to question the tenuous link between oil and authoritarianism. These analysts argue that correlations between abundant natural resources and authoritarianism cannot show causality. Hence, after years of the resource curse canon, a growing number of observers argue that petroleum is wealth that can and does pay for education, health care, infrastructural development, and the establishment of democratic institutions (Ayuk \& Marques 2017; Haber \& Menaldo 2011; Heilbrunn 2014; Menaldo 2016; O'Connor et al. 2018).

The resource blessing framework offers an alternative perspective. It is counterintuitive to think that when oil companies began to deposit funds in government accounts, undesirable developmental outcomes necessarily follow. In a previous publication, I argued that it is necessary to understand the diverse conditions in each oil exporting country before production started to assess the subsequent impact of oil revenues on development (Heilbrunn 2014). The case of Chad is instructive. After the initial deposit of signature bonuses, President Idriss Déby Itno, who was formerly a warlord, seized the money to buy military hardware, contrary to agreements with the Consortium of oil companies and donors (Heilbrunn 2014:4; Stern 2000). Déby justified the seizure as his right to defend his regime against insurgencies and invest in education and health care. Indeed, the World Bank reports that in 2016, 87 percent of Chad's primary school age children attended classes; oil provided the revenues that were a 
mixed blessing for Chad's children, who were growing up under a harsh dictatorship.

However, nothing is simple, and the binary polemic obscures as much as it illuminates. Oil exporting countries build state agencies. In many countries, these agencies demonstrate the continuity of political settlements rather than discontinuity. Countries continue on the paths on which they were traveling before oil production. For example, in 1992, Ghanaians voted to approve a referendum to establish a republican democracy. Successive presidential elections resulted in parties alternating in power without coups or any contestation of results. Democratic elections predated oil discoveries, and Ghana has continued to enjoy democratic government since that time. The receipt of petroleum revenues did not move the Accra government or its military to intervene and impose authoritarian rule, as advocates of resource curse arguments might have predicted.

By understanding the conditions in effect when oil production begins, it is possible to comprehend how policymakers choose to manage resource revenues. This simple proposition is that countries under dictatorships remain authoritarian after the discovery of oil. For instance, in 2017, Heritage Oil and Gas reimbursed the Ugandan state for back taxes; President Yoweri Museveni used these revenues to extend "the presidential handshake" to reward clients and clansmen (Brophy \& Wandera 2020:78; Hickey \& Izama 2017:173). Although stories abound of leaders who use resource revenues to consolidate power, the inverse is also evident in Angola and Nigeria.

\section{Environmental disaster}

When spilled, oil is toxic. When burned off in illegal gas flaring, it pollutes the air. Oil exporters face numerous predicaments resulting from negligent extraction. Sometimes, the guilty party is absent. In 2015, oil soiled the coast of Angola's Cabinda Province. As reported in the Angolan offical press, no one took responsibility, which left the local population to clean up the spill (Agencia Angola Press 2015). In other circumstances, the oil company sometimes refuses to take responsibility. In 2013, spills in Chad implicated the China National Petroleum Company (CNPC). The CNPC refused to acknowledge involvement in the spill or pay to clean it up, so Chadian authorities suspended CNPC's contract (Nako 2014). Some companies try to minimize the cost of the disasters, despite evidence to the contrary. Suzana Sawyer tells how companies in Ecuador and Nigeria report a single measure of hydrocarbon pollutants to obscure and minimize the differences among toxic substances (2015:145). Perhaps the most egregious example has been the spills in the Niger Delta.

The Niger Delta serves as a poignant reminder of oil extraction's risks. Indeed, the United Nations Environmental Program issued a shocking report, stating that it will take decades to repair the damage in Ogoniland (UNEP 2011:12). Spills have despoiled fish stocks and ruined agricultural 
lands. This environmental degradation radicalized the local people who lost their livelihoods due to recurring oil spills (Adunbi 2015). Royal Dutch Shell, speaking for SPDC-Nigeria, stated that for most spills, its lawyers' interpretation of existing laws indicated the Nigerian government was responsible for cleanup (WAC Global Services 2003). In these instances, they simply walked away. However, given how long these spills have been occurring and the extent of environmental damage, it is difficult to avoid a conclusion of willful corporate negligence (Hennchen 2015:9). This perspective is precisely what one judge in the Netherlands concluded in January 2021, when the court ordered Royal Dutch Shell to pay unspecified damages for spills that caused widespread environmental damage in Oruma and Goi, two villages in the Niger Delta (Raval \& Munshi 2021).

In the Niger Delta, multiple non-governmental organizations (NGOs) and their leaders have struggled against corporate arrogance (Adunbi 2015:18). In vain, the NGOs have demanded compensation for the injustices imposed on the Niger Delta's residents. A consequential fury, Rebecca Timsar (2015:88-89) suggests, shaped the creation, absorption, and channeling of rebellion by youth groups, which is evident in resurgent Egbesu worship "firmly rooted in Ijaw historical cosmology." These NGOs denounce the SPDC executives, government officials, and local community leaders whose collusion has resulted in relentless poverty, unemployment, and despair.

Unemployment among the Niger Delta's youth is a serious consequence. To overcome their poverty, unemployed youths tap pipelines and sell crude oil on regional and international markets (Watts 2004:50; Peel 2010). Youths participate in "a dizzying and bewildering array of militant groups, militia, and so-called cults" (Watts 2008:8). According to Omolade Adunbi (2015:45), local populations believe that oil companies have irresponsibly polluted their land before absconding with their inheritance. Residents suffer unemployment and misery while living alongside wells that expatriate abundant wealth and give little succor to the Niger Delta people. Herein is the story that Adunbi, Watts, and others have told.

In May 2013, the billboard below (Figure 1) greeted travelers entering Yenagoa, Bayelsa State. The wholesome young man pledges to avoid drugs and cult groups. His is an optimistic image of Delta youth. Whereas the billboard displays hope, the residents' continued destitution has contributed to violence, desperation, and drug abuse. Adunbi (2015) emphasizes the local belief that oil companies excluded the Niger Delta's youth from employment, education, and opportunities while extracting incredible riches for shareholders of international corporations headquartered in Europe and North America.

The organization of petroleum theft is a major activity that implicates high-ranking military and navy officials, politicians, and national and international oil executives (Watts 2004, 2008:8). Estimated losses of around 20 percent of Nigeria's production due to oil theft seem staggering. Ngozi Okonjo-Iweala states that in 2012, oil bunkering diverted an average of 
Figure 1. Government of Bayelsa State Billboard at entry to Yenagoa, Capitol of Bayelsa State, Nigeria. John Heilbrunn photo from personal files, 2013.

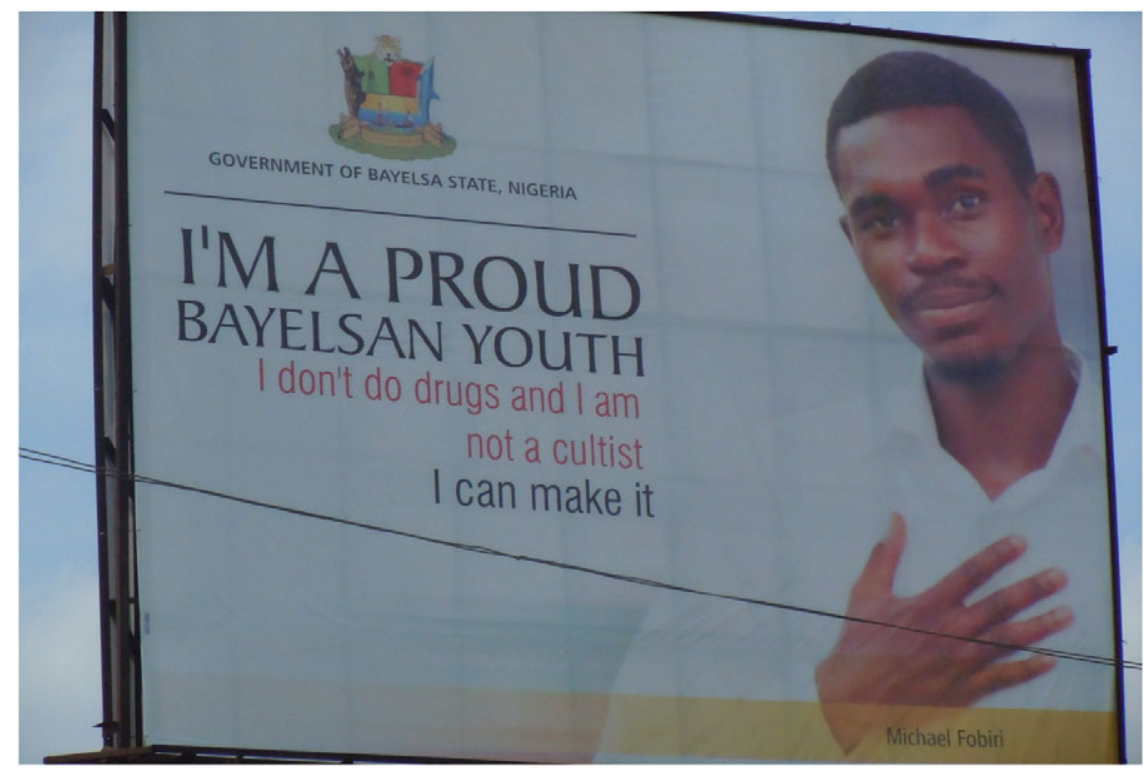

150,000 barrels a day from Niger Delta wells and accounted for losses of approximately USD1 billion a month (Okonjo-Iweala 2018:41). The tapping of pipelines causes explosions and oil spills for which, in case after case, Shell Nigeria blamed local populations for causing the environmental disasters (WAC Global Services 2003; Shell Nigeria 2014).

However, the extraordinary quantities of crude that are stolen could only occur with the connivance of local government councils, state governments, and officials in the Federal Government (Davis 2007:5; Gelber 2015; Katsouris \& Sayne 2013). The trade involves young men who tap pipelines, offload barrels onto barges and onshore tankers, or refine gasoline in artisanal refineries to distribute regionally (Gelber 2015:276, 280; Oruwari 2006:3; Watts 2006a:22; Watts 2008:15). The petroleum disappears through "deeply entwined" webs of people in oil companies, the state, and local communities (Gelber 2015:274-75, 285). Once the oil enters international waters, brokers sell it and transfer payments to shadow networks in Nigeria and abroad (Ellis 2016:86).

Because the various networks that profit from oil production exclude the Delta's Ijaw, Itsekiri, and Ogoni communities, these populations militantly oppose the FGN and oil companies that, as Adunbi (2015) emphasizes, took their birthright and gave nothing in return. Militants thus justify protection rackets, toll collection (passage), and fees as "late" payments (Adunbi 2015:197). They resent the northern military leaders who governed Nigeria 
for most of its independent history and treated oil revenues as their personal wealth (Siollun 2019:197-98). People complain that Abuja, the Federal capital, thrived only because of stolen oil wealth (Adunbi 2015:163). Meanwhile, the state refuses to protect its citizens from careless and arbitrary corporate negligence (Adunbi 2015:162; Watts 2006b; Watts 2015; Gelber 2015).

In an attempt to mediate the costly conflict in the Niger Delta, President Musa Yar'Adua proclaimed an amnesty program in 2009. However, local communities' demands for jobs, help in cleaning up oil spills, and a greater share of oil wealth went unanswered (Adunbi 2015:219). The amnesty program did nothing to alleviate the alienation of the youth from "political, civil, social, customary, and religious authority" (Watts 2018:479). Young men continued to join gangs and to serve as foot soldiers for extraordinarily powerful "godfathers" who had influence over decision-making in Abuja and each petroleum exporting state (Hellerman 2010; Sklar, Onwudiwe, \& Kew 2006). The influence of the godfathers in Nigeria, which is hard to overstate, is indicative of the perverse incentives in the post-authoritarian country. In this regard, petroleum is one element yet hardly the main cause of alienation in Nigerian society.

\section{Communities}

Oil communities include individuals on whom oil production has a direct and discernable impact. Southwestern Chad, where the Consortium of oil companies has been lifting oil, has a tropical climate and largely agrarian population. Chad is a landlocked former French colony that has received scant scholarly attention. The story of oil production in Chad began in 1977, when Conoco obtained an exploration license from the government (Nolutshungu 1996:94). Elf Aquitaine (today Total) objected to the entry of an American company (Nolutshungu 1996; Petry \& Bambé 2005). Conoco subsequently located reserves with a crude between $18.8^{\circ}$ and $25^{\circ}$ API gravity (Bacon \& Tordo 2004:23; Nolutshungu 1996). However, complex production logistics and political instability interfered with oil production.

In 1991, President Déby approached Esso, Shell, Elf, the Caisse Française du Développement, and the World Bank to figure out how to start production. Negotiations resulted in the World Bank guaranteeing loans to develop the Doba fields and construct the Chad-Cameroon Pipeline Project. ${ }^{2}$ It was an enormous success for Déby, who viewed oil as a means to break free from postcolonial relations (Nolutshungu 1996:298). He agreed to establish a number of offices, open offshore accounts to receive payments, and use revenues for development purposes. Despite the misgivings of some World Bank staff members, the agreement went through, and the Consortium began drilling for oil.

The agreement, however, was doomed. First, the World Bank team that negotiated the agreements had an inadequate understanding of internal Chadian politics (Gary \& Reisch 2005:42-48). The team failed to recognize 
that for Déby, oil revenues were windfalls (Behrends \& Hoinathy 2017:58). Although the World Bank demanded that oil revenues be used to finance development projects, Chadian communities received little in the way of training or local content transfers. Events in Chad affirmed Raymond Vernon's concept of an obsolescing bargain (Vernon 1971; Gould \& Winters 2007). Once Déby began to receive revenues in 2002, he immediately purchased arms and declared he had a right to use the funds as he saw fit. It quickly became clear that World Bank officials had "grossly overestimated" their ability to influence the former warlord; they had behaved as though he was weak, disengaged, and amenable to their tutelage (Pegg 2009:312). However, Déby was neither weak nor disengaged; rather, he was duplicitous and unambiguously corrupt. Hence, when his nephews Timane and Tom Erdimi organized a rebel force that in 2016 invaded N'Djaména, Déby denounced his agreement with the World Bank and stopped deposits into the offshore accounts.

An influx of capital had a direct impact on the Chadians who lived in communities near the installations and interacted directly with the Consortium. Dignitaries in local communities negotiated directly with the Consortium in spite of their relatively weak positions (Leonard 2016). Within a short time, internal social cleavages emerged in agrarian communities near the Oil Field Development Area (OFDA) in Bero, Komé, and Miandoum (Leonard 2016:23). First, literate people sold letter-writing services to help citizens who wished to make claims regarding ownership, damages, and grievances, or to mediate disputes (Leonard 2016:44, 48; Barclay \& Koppert 2007). Second, when land increased in value, the Consortium set a non-negotiable scale (bareme) for what it would pay for damages (Leonard 2016:70-74). The commodification of land and literacy in southern Chad introduced relations consistent with a "nearly neoliberal state" (Leonard 2016:67-68). Production transformed the local community and empowered entrepreneurial actors in southern Chad.

Finally, construction of the Chad-Cameroon Pipeline Project began while there was ongoing instability in the northern Borkou/Ennedi/Tibesti (BET) region. This mountainous desert region had been the historic point of departure for numerous guerilla movements. The Erdimi twins began their revolt from the BET region, where they received local support. Déby seized oil revenues to buy arms, reward his clients, and weaken traditional authorities (Debos 2016:143). Internal rivalries among members of Déby's clan reflected competition among factions in his Bideyat Zaghawa ethnicity. Chad was neither at war nor in peace (Debos 2013:48). Although the country was exporting oil and receiving resource rents, communities in southwestern Chad continued as before the beginning of production.

\section{Corruption}

Corruption, the abuse of position for private gain, is widespread and systemic in many African oil exporting countries. Whether discussing Nigeria's 
"missing billions" (Katsouris \& Sayne 2013; Wallis 2013; Premium Times), the dos Santos clan's fortune (Forsythe et al. 2020), Claudia Sassou-Nguesso's USD7 million New York City apartment (Global Witness 2019), the almost USD2 billion that Mozambican authorities embezzled from natural gasbacked loans (Friends of the Earth International 2020), or Teodorin Obiang Nguema's houses in California, South Africa, and Paris (Le Monde 2019), the response to Carlos Leite and Jens Weidman's 1999 question 'Does Mother Nature Corrupt?' is a resounding yes! Many alleged cases of malfeasance are evident.

Leakage of resource revenues is unfortunately common in oil exporting countries. In Nigeria, Equatorial Guinea, Angola, and Chad, corruption is far more than a symptom of misrule. It is a breakdown of constraints on public officials and employees of private oil companies. On one hand, officials believe they have impunity. Presidents in many oil exporting African countries control the accounts into which oil companies deposit taxes, fees, and bonuses; they see these accounts as slush funds for their personal use (Collier et al. 2010). On the other hand, employees of oil companies want to increase the profits for shareholders, even if that means they must break laws. They are sometimes willing to bend rules to secure contracts for lucrative reserves. In part, quick money in Nigeria, Angola, Equatorial Guinea, and Chad encourages people who want to make profits. However, to focus only on corrupt incidents obscures the extraordinary growth and opening of political expression occurring in many oil exporting countries. In this regard, oil has been a blessing.

Corruption is a term commonly used in analyses of many oil exporting countries. The many and varied reasons for systemic corruption suggest that oil companies do not care about a host regime's due diligence (Ayuk \& Marques 2017:25), and controls over dishonesty are absent. In Tanzania, discoveries of 57.25 trillion cubic feet (TCF) of recoverable natural gas preceded allegations that authorities had embezzled resource revenues (Choumert-Nkolo 2018; Poncian \& Jose 2019). In Mozambique, Anadarko and ENI announced the discovery of enormous natural gas fields. Shortly thereafter, government officials allegedly solicited loans over USD1.4 billion, or 78 percent of the country's GDP (IMF 2019b:5; Tvedten \& Picardo 2018:6; Friends of the Earth 2020; Kroll Associates 2017; Orre \& Rønning 2017:12). In both cases, few controls prevented officials from illicit enrichment. Scandals became examples of too much money too quickly available in a state with too few controls.

Nigeria has lived with "pervasive, massive, and unabashed malfeasance throughout the public and private sectors" (Lewis 2007:140). In the twentieth century, a succession of military dictators countenanced the theft of stunning sums from the oil sector. The country became a showcase of how oil facilitates corruption (Gillies 2020; Arezki \& Gylfason 2013; Sala-i-Martin \& Subramanian 2013). In 2013, the governor of the Nigerian Central Bank submitted a politically explosive letter to President Goodluck Jonathan in which he alleged that the NNPC had stolen USD50 billion in crude oil earnings 
(Sanusi 2013). European authorities launched investigations of Diezani Alison-Madueke, whom they eventually detained in London while British and Nigerian officials scrutinized her accounts to recover stolen assets (Munshi 2020).

A second case started in 1998 when the Italian supermajor, ENI, and Shell allegedly transferred an estimated USD1.1 billion to Malabu, a firm owned by General Sani Abacha's Petroleum Minister Dan Etete (Olawoyin 2020a). The oil companies wanted to acquire exploration/production rights to OPL 245 and its 560 million barrels of oil. It took years for judicial authorities to unravel the case and recover some of the stolen assets. The trial in Milan concluded with prosecutors demanding a ten-year prison sentence for Etete, eight years for former ENI executives Claudio Descalzi and Paolo Scaroni, and seven years four months for Malcolm Brinded, Shell's former head of upstream operations (Olawoyin 2020a). Although the Nigerian government had tried to recover the money distributed to former President Goodluck Jonathan, former Attorney General Mohammed Adoke, and former Petroleum Minister Alison-Madueke, Etete was practically untouchable (Olawoyin 2020b).

In Equatorial Guinea, the alleged corruption of Obiang Nguema's clan has resulted in wide-ranging investigations in France, the United States, and South Africa (Rice 2012). Hannah Appel (2015:253; 2020:27-28) observes how at different stages in the value chain, corrupt proceeds may be used to sustain a repressive and corrupt regime. Compared to Nigeria, Equatorial Guinea is a small producer, with reserves of around 1.1 billion barrels from which, in 2016, oil companies extracted 280,000 barrels a day (World Bank 2019). Although its 1.2 million people live in what was once one of the world's fastest growing economies, it was also one of the most inequitable. The Obiang clan dominates the state to such a degree that close family members own the companies that furnish security, transportation, and the apartments for oil company personnel. Indeed, the president's son, Teodorin Obiang Nguema, was infamous for his collection of rare automobiles, his real estate in California and on the Indian Ocean coast between Cape Town and Durban, and apartment buildings in Paris, all on a modest minister's salary (Gurrey 2012).

Ricardo Soares De Oliveira begins his elegant study of Angola's postwar reconstruction with the slogan "Angola starts," but by the book's conclusion, he despairs that a deeply corrupt and entrenched oligarchy has left most Angolans impoverished to "suffer and die of preventable diseases and have a life expectancy that barely reaches 50" (2015:211-12). The history of this shocking inequality begins at Angola's independence in 1975, when its political elite engaged in an intractable civil war (Cramer 2006; Messiant 2006; Soares De Oliveira 2015). Between 1975 and 2002, two principal combatants, the MPLA under Jose Eduardo Dos Santos and Jonas Savimbi's National Union for the Total Independence of Angola (União Nacional para a Independência Total de Angola -UNITA) fought for control of the country's enormous natural resource wealth. While the MPLA diverted oil revenues to 
finance its war effort, UNITA seized rents from the diamond mines. Neither Dos Santos nor Savimbi had a compelling interest in ending the war (Soares De Oliveira 2007b). In effect, petroleum and diamonds financed a conflict that dragged on for decades, wasted a king's fortune, and cost countless lives.

After the war ended in 2002, the Dos Santos government launched an ambitious reconstruction program. The president's clan and associates reaped fortunes through corrupt networks and contracts (Soares De Oliveira 2015; Pearce et al. 2018). In 2017, João Lourenço, the newly elected general secretary of the MPLA and president, put an end to dos Santos clan's illicit behavior. To start, Lourenço dismissed Isabel dos Santos as head of Sonangol, launched investigations into how she and her late husband Sindika Dokolo had amassed billions, and seized her accounts (Freedberg et al. 2020; Forsythe et al. 2020). The Lourenço administration opened investigations into Isabel dos Santos's brother José Filomeno dos Santos and his management of the sovereign wealth fund, the Fundo Soberano de Angola (FSDEA), from which he allegedly embezzled USD500 million (Pilling 2019; Pearce et al. 2018). Authorities jailed the younger Dos Santos; his release within seven months suggests the clan enjoys continued immunity from prosecution and punishment (Jornal de Angola 2019). However, their unrestrained consumption of oil wealth had ended.

When oil prices increased from USD10.00 a barrel in 1999 to USD147.00 a barrel in 2008, the MPLA regime received a bonanza. It protected the "unregulated global capitalism of the neoliberal era and the activist capitalism of resource-rich states" (Soares De Oliveira 2015:169). Oil-backed loans from China helped Dos Santos centralize executive power and blur any lines between private and public sector oil revenue management (Soares De Oliveira 2015:173). Those days are over. A slowdown that began in 2016 preceded the collapse of oil prices due to the 2020 global pandemic. Hence, the culture of corruption that permeated Angola and its elites has ceded its position to austerity programs, calls for good governance, and economic retrenchment.

\section{Oil as Keyword?}

Whether framed as a blessing or a curse, oil is a productive keyword for African studies. Even in those circumstances where individuals use their positions to seize government wealth, it seems implausible that they can grab it all. More plausibly, oil revenues provide policymakers with the funds necessary to hire people who work in ministries, agencies, and departments. The resulting mix of policies, laws, and regulations constitute a country's fiscal regime, all elements of a more efficacious state. The influx of money gives a country's leaders the means to reduce inefficiencies. Of course, nothing is absolute or linear; however, contrary to the pessimistic determinism of resource curse arguments, this essay proposes that by enabling state construction, oil wealth contributes ultimately to better governance and less corruption. 
Hydrocarbon production accelerates an exporting country's integration into the world economy. Nigeria, for one example, has assumed a critical role in West Africa and the global economy, to which a constant parade of news stories in international newspapers such as The Financial Times attests to its importance. Of course, not all the stories are salutary; many are reports about astonishingly brazen corruption scandals. During the twenty-first century, African oil exporting countries experienced significant increases in GDP that accompanied their integration into the world economy. With the announcement that Nigerian public health officials detected the first case of COVID-19 on February 29, 2020, the pandemic had a decelerating impact on oil exporting economies. However, it seems likely that African oil exporting countries will continue to be crucial players in the global economy.

Oil as metaphor continues to animate research about petroleum and its impact on common people in oil exporting countries. Many analysts use "oil" to signify modernity, neoliberalism, globalism, local content, and so on. They contend that through neoliberal policies, political leaders thrust their countries into the global capitalist economy. Politicians have had no choice but to accept structural adjustment programs with unduly punitive conditions. Embedded in this critique is a notion that petroleum production introduces a network of donor organizations and "experts" who promulgate policies that often harm common African people. One undisputable critique of neoliberalism is that the analyses avoid counterfactual reasoning. Instead of asking what an oil exporting country might have experienced in the absence of reforms, they assert that oil is a curse. It therefore takes the position that petroleum necessarily condemns a country's people to lower incomes and life under the yoke of autocratic rule.

Oil wealth has diverse impacts under different political conditions. For example, local content requirements have a positive impact on African populations in oil exporting countries. Local firms in Angola, to some extent, have taken advantage of these laws to participate in reconstruction projects. In Chad, when the Consortium started field development, property values increased and residents paid literate neighbors who, for a fee, drafted letters for them, seeking compensation. In the Niger Delta, oil as wealth was no less a factor in the emergence of armed militia that targeted oil rigs. Threats of violence often convinced oil companies to declare a force majeur, stop production, and withdraw their personnel. Possible explanations for these events that aggravate an already tense situation include pervasive unemployment among a youthful population and the failure of oil companies to invest in regional development.

Corruption, often skulking in the background, occurs at different points in the oil value chain. In some countries, the dishonesty is systemic. Corruption in Nigeria has been evident in a succession of scandals involving astounding sums of money. Yet, the country's economy has continued to grow, and it is now the largest in Africa. However, whether discussing Nigeria, Equatorial Guinea, Angola, or Chad, impunity among high level officials 
enables corrupt transactions. People are not deterred from stealing money that is a direct outcome of oil production. Indeed, with the debatable exception of Ghana, practically all African oil exporting countries have experienced systemic corruption to greater or lesser effect. Hence, although oil is a chemical that can do nothing on its own, it correlates with unfortunate outcomes in low- and low-middle income African countries.

Since 1975, more and more African countries have explored for, discovered, and begun exporting oil. This growing number of producers attests to why oil is a keyword in African studies. It is a keyword that informs debates about the impact of natural resources on development and social well-being. For sure, oil is wealth. As wealth, oil enables countries to experience positive effects that include increased investments in education and health care. However, even in the best cases, growing wealth brings out the worst in human behavior. Corruption has been part of numerous scandals in oil exporting countries. Corporate greed is evident when companies seeking increased shareholder profit have negligently failed to maintain productive facilities. Only the most callous of observers can minimize the environmental catastrophes in places like the Niger Delta.

As a keyword in African studies, oil becomes synonymous with a variety of conditions that arise in exporting countries. Entry into the ranks of oil exporting countries triggers novel relations with international actors and organizations. Money from the petroleum industry influences political and social relations. An understanding of oil's centrality to economic growth and political development is a critical element of this keyword that is so important for so many exporting countries. This kind of analysis owes a debt to anthropology, economics, political science, and sociology. Viewing oil as a keyword in African studies seem an ideal method for linking different disciplines and bridging disciplinary silos.

\section{Acknowledgments}

I would like to acknowledge the excellent reviewers' comments I received and Benjamin Lawrance's outstanding editorial acumen. Of course, all remaining errors are mine alone.

\section{References}

Ablo, Austin Dziwornu. 2020. "Enterprise Development? Local Content, Corporate Social Responsibility and Disjunctive Linkages in Ghana's Oil and Gas Industry.” The Extractive Industries and Society 7: 321-17.

Adunbi, Omolade. 2015. Oil Wealth and Insurgency in Nigeria. Bloomington: Indiana University Press.

Agencia Angola Press. 2015. September 22. 
Alexeev, Michael, and Robert Conrad. 2009. "The Elusive Curse of Oil." The Review of Economics and Statistics 91 (3): 586-98.

Appel, Hannah. 2015. "Offshore Work: Infrastructure and Hydrocarbon Capitalism in Equatorial Guinea." In Subterranean Estates: Life Worlds of Oil and Gas, edited by Hannah Appel, Arthur Mason, and Michael Watts, 257-73. Ithaca: Cornell University Press.

- 2020. The Licit Life of Capitalism: US Oil in Equatorial Guinea. Durham: Duke University Press.

Appel, Hannah, Arthur Mason, and Michael Watts, editors. 2015. "Introduction: Oil Talk." In Subterranean Estates: Life Worlds of Oil and Gas, edited by Hannah Appel, Arthur Mason, and Michael Watts, 1-29. Ithaca: Cornell University Press.

Arezki, Rabah, and Thorvaldur Gylfason. 2013. "Resource Rents, Democracy, Corruption and Conflict: Evidence from Sub-Saharan Africa." Journal of African Economies 22 (4): 552-69.

Auty, Richard. 1994. "Industrial Policy in Six Large Newly Industrialising Countries: The Resource Curse Thesis.” World Development 22 (1): 11-26.

Ayuk, N.J., and João Gaspar Marques. 2017. Big Barrels: African Oil and Gas and the Quest for Prosperity. New York: Clink Street Publishing.

Bacon, Robert, and Silva Tordo. 2004. "Crude Oil Prices: Predicting Price Differentials Based on Quality.” World Bank Other Operational Studies 11250.

Barclay, Robert, and George Koppert. 2007. Chad Resettlement and Compensation Plan Evaluation Study: Main Report. Paris: Groupe d'Études des Populations Forestières Équatoriales.

Behrends, Andrea, and Remadji Hoinathy. 2017. “The Devil's Money: A Multi-Level Approach to Acceleration and Turbulence in the Oil-Producing Southern Chad." Social Analysis 61 (3): 56-72.

Brophy, Kathleen, and Peter Wandera. 2020. "Keeping Corruption in Check in Uganda's Oil Sector? Uganda's Challenge to Let Everyone Eat, and Not Just the Lucky Few." In Oil Wealth and Development in Uganda and Beyond, edited by Arnim Langer, Ukoha Ukiwo, and Pamela Mbabazi, 75-102. Leuven: Leuven University Press.

Calder, Jack. 2014. Administering Fiscal Regimes for Extractive Industries: A Handbook. Washington: the International Monetary Fund.

Choumert-Nkolo, J. 2018. "Developing a Socially Inclusive and Sustainable Natural Gas Sector in Tanzania." Energy Policy 118 (July): 356-71.

Collier, Paul, Rick van der Ploeg, Michael Spence, and Anthony J. Venables. 2010. "Managing Resource Revenues in Developing Economies." IMF Staff Papers (57): 84-118.

Corden, W. Max, and Peter Neary. 1982. "Booming Sector and Deindustrialisation in a Small Open Economy.” The Economic Journal 92: 825-48.

Cramer, Christopher. 2006. Civil War is not a Stupid Thing: Accounting for Violence in Developing Countries. London: Hurst and Company.

Davis, Stephen. 2007. "Shifting Trends in Oil Theft in the Niger Delta." Legaloil.com Information Paper No. 3: 1-14.

Debos, Marielle. 2013. "La guerre des préfets: Répression, clientélisme et illégalismes d'État dans l'entre-guerres tchadien.” Politix 26 (104): 47-65.

- 2016. Living by the Gun in Chad: Combatants, Impunity and State Formation. Translated by Andrew Brown. London: Zed Books. 
Deléchat, Corinne, Ejona Fuli, Dafina Mulaj, Gustavo Ramirez, and Rui Xu. 2015. "Exiting from Fragility in sub-Saharan Africa: The Role of Fiscal Policies and Fiscal Institutions." IMF Working Paper WP/15/268.

Dunning, Thad. 2008. Crude Democracy: Natural Resource Wealth and Political Regimes. New York: Cambridge University Press.

Ellis, Stephen. 2016. This Present Darkness: A History of Nigerian Organized Crime. New York: Oxford University Press.

Ferguson, James. 2005. "Seeing Like An Oil Company." American Anthropologist 107 (3): 377-82.

- 2006. Global Shadows: Africa in the Neoliberal World Order. Durham: Duke University Press.

- 2010. "The Uses of Neoliberalism." Antipode 41 (S1): 166-84.

Forsythe, Michael, Kyra Gurney, Scilla Alecci, and Ben Hallman. 2020. "How U.S. Firms Helped Africa's Richest Woman Exploit Her Country's Wealth.” The New York Times January 19.

Foucault, Michel. 2004. The Birth of Biopolitics: Lectures at the Collège de France 1978-1979. Edited by Michel Senellart. Translated by Graham Burchell. New York: Picador/ Palgrave MacMillan.

Freedberg, Sydney P., Scilla Alecci, Will Fitzgibbon, Douglas Dalby, and Delphine Reuter. 2020. "How Africa's Richest Woman Exploited Family Ties, Shell Companies and Insider Deals to Build an Empire." Luanda Leaks https://www.icij. org/investigations/luanda-leaks/how-africas-richest-woman-exploited-familyties-shell-companies-and-inside-deals-to-build-an-empire/.

Friends of the Earth International/Les Amis de la Terre France. 2020. De l'Eldorado Gazier au Chaos: Quand la France Pousse le Mozambique dans le Piège du Gaz. Paris (Juin).

Gary, Ian, and Nikki Reisch. 2005. Chad's Oil: Miracle or Mirage: Following the Money in Africa's Newest Petrostate. Baltimore: Catholic Relief Services.

Gelber, Elizabeth. 2015. "Black Oil Business: Rogue Pipelines, Hydrocarbon Dealers, and the 'Economics' of Oil Theft." In Subterranean Estates: Life Worlds of Oil and Gas, edited by Hannah Appel, Arthur Mason, and Michael Watts, 274-90. Ithaca: Cornell University Press.

Gillies, Alexandra. 2020. Crude Intentions: How Oil Contaminates the World. New York: Oxford University Press.

Global Witness. 2019. "Millions of apparently stolen dollars paid for apartment in Trump property: Congo case shows authorities must act to close real estate money-laundering loopholes." (April).

Gould, John, and Matthew Winters. 2007. "An Obsolescing Bargain in Chad: Shifts in Leverage between the Government and the World Bank." Business and Politics 9 (2): 1-34.

Gurrey, Béatrice. 2012. "Mandat d'arrêt contre le fils du président Obiang." Le Monde (14 Juillet).

Guyer, Jane I. 2015. "Oil Assemblages and the Production of Confusion: Price Flucturations in Two West African Oil-Producing Economies." In Subterranean Estates: Life Worlds of Oil and Gas, 237-252. Edited by Hannah Appel, Arthur Mason, and Michael Watts. Ithaca: Cornell University Press.

Haber, Stephen, and Victor Menaldo. 2011. "Do Natural Resources Fuel Authoritarianism? A Reappraisal of the Resource Curse." The American Political Science Review 105 (1): 1-26.

Harvey, David. 2005. A Brief History of Neoliberalism. New York: Oxford University Press. 
Heilbrunn, John R. 2014. Oil, Development, and Democracy in Africa. New York: Cambridge University Press.

Hellermann, Pauline von. 2010. "The chief, the youth, and the plantation: communal politics in southern Nigeria." The Journal of Modern African Studies 48 (2): 259-83.

Hennchen, Esther. 2015. "Royal Dutch Shell in Nigeria: Where Do Responsibilities End?” Journal of Business Ethics 129: 1-25.

Hickey, Sam, and Angelo Izama. 2017. "The Politics of Governing Oil in Uganda: Going Against the Grain." African Affairs 116 (463): 163-85.

Hilson, Abigail Efua, and Jesse Salah Ovadia. 2020. "Local Content in Developing and Middle-Income Countries: Towards a More Holistic Strategy." The Extractive Industries and Society 7: 253-62.

International Monetary Fund (IMF). 2018. "Angola: Selected Issues." Washington: International Monetary Fund.

- 2019a. "Chad: Fifth Review Under the Extended Credit Facility Arrangement and Financing Assurances Review-Press Release; Staff Report; Staff Supplement; and Statement by the Executive Director for Chad." IMF Country Report No. 19/399.

— 2019b. "Republic of Mozambique: Diagnostic Report on Transparency, Governance and Corruption.” IMF Country Report No. 19/276.

Jensen, Nathan, and Leonard Wantchekon. 2004. "Resource Wealth and Political Regimes in Africa." Comparative Political Studies 37 (3): 816-41.

Jornal de Angola. 2019. Luanda. March 25.

Karl, Terri Lynn. 1997. The Paradox of Plenty: Oil Booms and Petro-States. Berkeley: University of California Press.

Katsouris, Christina, and Aaron Sayne. 2013. Nigeria's Criminal Crude: International Options to Combat the Export of Stolen Oil. London: Chatham House.

Kroll Associates. 2017. "Independent Audit Related to Loans Contracted by ProIndicus S.A., EMATUM S.A. and Mozambique Asset Management S.A.” Report Prepared for the Office of the Public Prosecutor of the Republic of Mozambique (June 23).

Leite, Carlos, and Jens Weidmann. 1999. "Does Mother Nature Corrupt? Natural Resources, Corruption, and Economic Growth." IMF Working Paper WP/99/85.

Le Monde avec AFP. 2019. "Un vintaine de voitures confisquées au clan Obiang vndues aux enchère en Suisse pour 21.6 millions d'euros.” September 30.

Leonard, Lori. 2016. Life in the Time of Oil: A Pipeline and Poverty in Chad. Bloomington: Indiana University Press.

Lewis, Peter M. 2007. Growing Apart: Oil, Politics, and Economic Change in Indonesia and Nigeria. Ann Arbor: The University of Michigan Press.

McCauley, Darren A., Raphael J. Heffron, Hannes Stephan, Kirsten Jenkins. 2013. "Advancing Energy Justice: The Triumvirate of Tenets." International Energy Law Review 32 (3 ): 107-10.

Messiant, Christine. 2006. 1961, L’Angola colonial, histoire et société: Les prémisses du mouvement nationaliste. Basel: P. Schlettwein Publishing Switzerland.

Menaldo, Victor. 2016. The Institutions Curse: Natural Resources, Politics, and Development. New York: Cambridge University Press.

Munshi, Neil. 2020. "Nigeria Intensifies Corruption Drive After Fall in Global Ranking," The Financial Times (January 30).

Nako, Madjiasra. 2014. “Chad Fines China’s CNPC Unit \$1.2 Billion for Environmental Damage.” Reuters.com. March 21.

Nankani, Gobind. 1979. "Development Problems of Mineral Exporting Countries." World Bank Staff Working Paper No. 354. 
Nolutshungu, Sam C. 1996. Limits of Anarchy: Intervention and State Formation in Chad. Charlottesville: University of Virginia Press.

O’Connor, Kelsey J., Luisa R. Blanco, and Jeffrey B. Nugent. 2018. "Does Oil Really Curse Democracy? A Long-Run Time Series Analysis of 127 Countries.” Resources Policy 57: 264-77.

Okonjo-Iweala, Ngozi. 2018. Fighting Corruption is Dangerous: The Story Behind the Headlines. Cambridge: MIT Press.

Olawoyin, Oladeinde. 2020a. "Malabu Scandal: Italian Prosecutors Want Former Nigerian Oil Minister Jailed for 10 Years.” Premium Times (July 23).

- 2020b. "Malabu Scandal: Shell 'Writes Down' OPL 245 License.” Premium Times (July 30).

Orre, Aslak, and Helge Rønning. 2017. Mozambique: A Political Economy Analysis. Oslo: Norwegian Ministry of Foreign Affairs.

Oruwari, Yomi. 2006. "Youth in Urban Violence in Nigeria: A Case Study of Urban Gangs from Port Harcourt." Niger Delta Economies of Violence Working Paper No. 14. University of California, Berkeley: Institute of International Studies.

Ovadia, Jesse Salah. 2014. "Local Content and Natural Resource Governance: The Cases of Angola and Nigeria." The Extractive Industries and Society 1: 137-46.

—. 2016a. "Local Content Policies and Petro-Development in Sub-Saharan Africa: A Comparative Analysis.” Resources Policy 49: 20-30.

— 2016b. The Petro-Developmental State in Africa: Making Oil Work in Angola, Nigeria, and the Gulf of Guinea. London: Hurst and Company.

Pearce, Justin, Didier Péclard, and Ricardo Soares De Oliveira. 2018. "Angola's Elections and the Politics of Presidential Succession." African Affairs 117 (466): 146-60.

Peel, Michael. 2010. A Swamp full of Dollars: Pipelines and Paramilitaries at Nigeria's Oil Frontier. Chicago: Lawrence Hill Books.

Pegg, Scott. 2009. "Chronicle of a Death Foretold: The Collapse of the ChadCameroon Pipeline Project." African Affairs 108 (431): 311-20.

Petry, Martin, and Naygotimti Bambé. 2005. Le pêtrole du Tchad: Rêve ou cauchemar pour les populations. Paris: Éditions Karthala.

Pilling, David. 2019. “Africa: can João Lourenço cure Angola of its crony capitalism?” The Financial Times (July 8).

Poncian, Japhace, and Jim Jose. 2019. "Resource Governance and Community Participation: Making Hydrocarbon Extraction Work for Tanzania." Resources Policy 62: 84-93.

Premium Times. Abuja, Nigeria. Various Dates.

Raval, Anjli, and Neil Munshi. 2021. "Shell Loses Dutch Case Over Nigeria Oil Spills." The Financial Times (January 30).

Rice, Xan. 2012. "Mansions, memorabilia and a personal log tax." The Financial Times (June 20).

Ross, Michael L. 2001. “Does Oil Hinder Democracy?” World Politics 53 (3): 325-61.

- 2012. The Oil Curse: How Petroleum Wealth Shapes the Development of Nations. Princeton: Princeton University Press.

Sachs, Jeffrey D., and Andrew M. Warner. 1995. "Natural Resource Abundance and Economic Growth.” National Bureau of Economic Research Working Paper 5398.

Sala-i-Martin, Xavier, and Arvind Subramanian. 2013. "Addressing the Natural Resource Curse: An Illustration from Nigeria." Journal of African Economies 22 (4): 570-615. 
Sanusi, Sanusi Lamido. 2013. "Letter from CBN Gov to President Jonathan." (Reprint) SaharaReporters (December 10).

Sawyer, Suzana. 2015. "Crude Contamination: Law, Science, and Indeterminacy in Ecuador and Beyond.” In Subterranean Estates: Life Worlds of Oil and Gas, edited by Hannah Appel, Arthur Mason, and Michael Watts, 126-48. Ithaca: Cornell University Press.

Sayne, Aaron, Alexandra Gilles, and Christina Katsouris. 2015. Inside NNPC Oil Sales: A Case for Reform in Nigeria. New York: Natural Resource Governance Institute.

Schubert, Jon. 2017. Working the System: A Political Ethnography of the New Angola. Ithaca: Cornell University Press.

Shaxson, Nicholas. 2007. Poisoned Wells: The Dirty Politics of African Oil. New York: Palgrave MacMillan

Shell Companies in Nigeria (Shell Petroleum Development Company of Nigeria Limited, Shell Nigeria Exploration and Production Company Limited and Shell Nigeria Gas Limited). 2014. “The UNEP Report” (https://s02.static-shell.com/ content/dam/shell-new/local/country/nga/downloads/pdf/2014bnotes/ unep.pdf.) Accessed June 19, 2018.

Shever, Elana. 2012. Resources for Reform: Oil and Neoliberalism in Argentina. Stanford: Stanford University Press.

Siollun, Max. 2019. Nigeria's Soldiers of Fortune: The Abacha and Obasanjo Years. London: C. Hurst \& Co.

Sklar, Richard L., Ebere Onwudiwe, and Darren Kew. 2006. "Nigeria: Completing Obasanjo's Legacy,” Journal of Democracy 17 (3): 100-15.

Smil, Vaclav. 2003. Energy at the Crossroads: Global Perspectives and Uncertainties. Cambridge: MIT Press.

Soares De Oliveira, Ricardo. 2007a. "Business Success, Angola Style: Post-Colonial Politics and the Rise and Rise of Sonangol." The Journal of Modern African Studies 45 (4): 595-619.

- 2007b. Oil and Politics in the Gulf of Guinea. London: Hurst and Company. . 2015. Magnificent and Beggar Land: Angola Since the Civil War. London: Hurst and Company.

Sovacool, Benjamin K., and Michael H. Dworkin. 2015. "Energy Justice: Conceptual Insights and Practical Applications." Applied Energy 142: 435-44.

Stern, Babette 2000. "Le Tchad a acheté des armes avec l'argent du pêtrole." Le Monde (22 Novembre).

Timsar, Rebecca Golden. 2015. "Oil, Masculinity, and Violence: Egbesu Worship in the Niger Delta of Nigeria." In Subterranean Estates: Life Worlds of Oil and Gas, edited by Hannah Appel, Arthur Mason, and Michael Watts, 72-89. Ithaca: Cornell University Press.

Tsui, Kevin K. 2011. "More Oil, Less Democracy: Evidence from Worldwide Crude Discoveries.” The Economic Journal 121 (551): 89-115.

Tvedten, Inge, and Rachi Ricardo. 2018. “'Goats eat where they are tied up': Illicit and habitual corruption in Mozambique." Review of African Political Economy 45 (158): 541-57.

UNEP. 2011. Environmental Assessment of Ogoniland. Geneva: United Nations Environment Programme.

Vernon, Raymond. 1971. Sovereignty at Bay: The Multinational Spread of US Enterprises. New York: Basic Books.

WAC Global Services. 2003. "Peace and Security in the Niger Delta: Conflict Expert Group Baseline Report, Working Paper for SPDC.” WAC Global Services. 
Wallis, William. 2013. "Nigeria’s central bank believes $\$ 50$ missing from oil sales." The Financial Times (June 12).

Watts, Michael J. 2004. "Resource Curse? Governmentality, Oil and Power in the Niger Delta, Nigeria." Geopolitics 9 (1): 50-80.

- 2006a. "Petro-Insurgency or Criminal Syndicate? Conflict, Violence and Political Disorder in the Niger Delta." Niger Delta Economies of Violence Working Paper No. 16. University of California, Berkeley: Institute of International Studies.

— 2006b. "Youth in Urban Violence in Nigeria: A Case Study of Urban Gangs from Port Harcourt." Niger Delta Economies of Violence Working Paper No. 14. University of California, Berkeley: Institute of International Studies.

- 2008. "Imperial Oil: The Anatomy of a Nigerian Oil Insurgency." Niger Delta Economies of Violence Working Paper No. 18. University of California, Berkeley: Institute of International Studies.

— 2015. "Securing Oil: Frontiers, Risk, and Spaces of Accumulated Insecurity." In Subterranean Estates: Life Worlds of Oil and Gas, edited by Hannah Appel, Arthur Mason, and Michael Watts, 211-36. Ithaca: Cornell University Press.

2018. "Frontiers: Authority, Precarity, and Insurgency at the Edge of the State." World Development 101 (5): 472-88.

Williamson, John. 1993. "Democracy and the 'Washington Consensus'." World Development 21 (8): 1329-36.

World Bank. 2000. "Management Report and Recommendation in Response to the Inspection Panel Investigation Report," Cameroon Petroleum Development and Pipeline Project (Loan no. 7020 CM).

. 2019. "Chad: Second Programmatic Economic Recovery and Resilience Policy Financing: Proposed Development Policy Grant." Report N.: PGD76. Washington: The International Development Association.

\section{Notes}

1. In this essay, oil refers to hydrocarbons, oil, petroleum, and oil and gas condensate. I use these terms interchangeably.

2. Full disclosure: in 1999 and 2000, I was a Senior Public Sector Management Specialist in the World Bank's Poverty Reduction and Economic Management Anchor. My responsibilities were to ensure that lending and technical assistance programs complied with the World Bank's policies on governance and anticorruption. Evaluation of the Chad-Cameroon pipeline project was among my responsibilities. 